\title{
Book Review: Caste: The Origins of Our Discontents
}

\author{
Isaac Kim* \\ Lafayette High School, Lafayette Parish School System, Lafayette, LA, United States
}

Keywords: race, diversity, culture, discrimination, upheaval, systemic racism

\section{A Book Review on}

Caste: The origins of our discontents

by Isabel Wilkerson (2020). New York, NY: Random House. 388 pp.

Caste, by American journalist and Pulitzer Prize winner Isabel Wilkerson, is a book that exposes the struggles the United States has experienced due to the preservation of the constraints and legacy of slavery that still leaves its mark on our modern society. It attempted to articulate the incessant confusion that ensues as two sides struggle to either maintain or tear down the de facto caste boundaries that have been oppressing one side of the American society. The latent caste dwells on many different aspects of society and notable peoples who have challenged the system. The author has also been noted for her previous work known as The Warmth of Other Suns, detailing the great migration of millions of African Americans leaving the South to escape the brunt of Jim Crow. She has also won the Pulitzer Prize for journalism along with the National Humanities Medal. Along with this line of work, Caste describes the intricate network placed within the United States to constrain the African Americans in society, a literal caste system designed to make sure that a race takes "their role" in society.

The network of caste functioning in many different situations still exists in American society from sports to science, criminal justice to poverty. Aligning with the perspective of critical race theory, this book specifically presents how a race came to enforce a role that forces suppression by outlining how the suppression not only takes a toll on the suppressed caste, but also on the enforcers in society. Wilkerson provides many historic examples and even her own accounts and emphasizes the cost that the caste system takes on the society it encompasses, especially the extreme amount of stress and turmoil that comes from all sides through attempts to keep the system in place. The suppressed become a miserable class that only grows to accept their own misery, with even the behaviors and innate personalities of a person being altered heavily by one's presumed role in a society, which is all based upon a shaky concept of race in America.

Through the use of many narratives throughout the book, Wilkerson compares the caste system in America with those that could have been found globally, from the subcontinent of India to the forced oppression that was subjected to people under Nazi Germany. This comparison allows readers to see the innate system that is being upheld, but through a unique analytic lens. With such comparisons, the author points out the false sense of entitlement, superiority, and policing that the upper-class places on itself, a damaging illusion that ends up doing more harm than good as the entirety of society loses out on many opportunities to advance. She especially enunciates the use of propaganda and false senses of superiority in her explanation of caste, which explains how the lower caste is eventually led to believe that their role on the bottom rungs of society was naturally the role they were supposed to hold. She argues that caste will, in the end, damage so many people, literally leading to death for many, and develop unnecessary social turmoil due to the class boundaries it creates. Most of the book discloses this deep-strung caste society that even turns one against their own race, as the caste becomes innate within a group, and the suppression manifests itself. This central theme clearly reveals how white supremacy becomes morally and legally justified despite the absence of official de jure segregation (Orbe and Allen, 2008). 
Wilkerson also examines attempts to subvert the caste system and reveals that even such attempts were not as obviously "change based" as demonstrated in the 2008 election. She rather highlights the backlash and the pushes against those attempts at change, while maintaining the stance that those changes would have helped society in general. In retrospect, many challenges to the caste system are duly noted, ranging from the free African Americans of the early United States to an African American president in our modern society. Overall, Wilkerson arrays and sheds light on a wide range of perspectives and accounts that the caste system based upon absurd guidelines is a sly concept that only damages American society, directly contradicting the values of democracy that America had supposedly found itself on.

The book, Caste, contains a multitude of narratives to deliver deep-running messages by showing many different aspects of American life from the perspectives of the people who had to live on the bottom rungs of the caste society. The narratives portray unveiling realities from the origins of the caste system to the modern day through stories like Satchel Paige's baseball career, writer Allison Davis' accounting of the South, and even the author's own experiences of the caste system. Interestingly, this work takes a new approach to analyze the innate trend of caste systems by comparing the American caste with the methods of Nazi Germany and the infamous Indian caste system, convincing the audience that any caste system destroys society by wrapping around all aspects of life.

The way the author presents her messages, backing main points with many smaller stories, is very effective in detailing a variety of circumstances and lifestyles, describing all aspects of life as well as her central message: caste is a menacing octopus that spreads its tentacles around all facets of life, devastating all that it touches so that nobody is truly benefited from it. Moreover, racism yields cumulative effects across institutional, social, economic, and political levels (De La Garza, 2015). Everything from the Charles Stuart case all the way to Wilkerson's own experiences with a plumber all ties into how caste has truly warped all aspects of life in an oppressive black hole that society cannot escape from. This perspective is strengthened by Wilkerson's decision to spread her messages among a network of different stories that only come together over the central message of caste. This micronarrative method well validates the argument that racism is a challenge that is ever dominant, emerging throughout every aspect of society, and a shadow that envelops the society even though the upper caste may not even see it (De La Garza and Ono, 2016).

Caste is very persuasive because of this specific methodology Wilkerson uses. The intricate blanket that caste acts as is made even more evident due to the fact that Wilkerson delivers her main themes through smaller stories. But something especially more noteworthy is the smaller ideals that appear within the stories as well. Wilkerson, as the book goes on, is constructing an image, as each critical aspect comes together to form a central idea much like how each small story comes together to display a central message. This comes not just from the similar ideals that occur in her stories, but also from the differences in them. The book is in fact organized by those smaller ideals that are behind the caste system, as the individual stories tell diverse aspects of the caste. Examples include the absorption of the caste identity by the bottom caste in attempts to try to avert the oppressive fist of the dominant caste established by the history of "sellouts" that have existed since the times of slavery; the sustaining need for the dominant caste to control the lower caste to perpetuate their power is demonstrated by an incident in Oakland where a father was overruled by a dominant stranger in addressing his own son, and; the purposeful lack of attention given to the lower caste during times of crisis is exemplified by the lack of attention given to a bombing incident in 2018 Austin Texas based on caste lines. These stories that illustrate what builds and sustains caste are how Wilkerson claims that racism extends to all aspects of life, not a solid entity that is a mere obstacle and infuses a series of false ideals that have clogged every path available with roadblocks.

Consistently, Wilkerson focuses on the continuation of a caste system, stating that the legacy of slavery and racism in America is not a mere thorn in history that still causes bleeding today. It is something that was always innate in American society, resulting from the attempts by the dominant caste to assert a false sense of dominance over the lower caste due to the ideals of a previously slave-holding society. In fact, with many comparisons and testimonies from the societies of Nazi Germany and India in particular, caste is recognized to be more of a way that society functions, as every individual action must be aligned into the caste system as well. This perspective serves to support the idea that caste is not only based on American circumstances, but that caste can exist everywhere.

Many of the stories Wilkerson uses, like the previously mentioned Austin bombing, are from modern times, while some, like the references to the Nazis, are from a bygone age. Emphasizing the fact that caste encompasses every aspect of life across the relevant American timeline, she has compiled stories from a variety of backgrounds across a variety of ages and successfully created her analogy of caste: the dark octopus that stretches its tentacles across all facets of society. This variety of stories from differing times symbolizes the reiterating social inequality descending continuously, reminding that caste is not a relic of the past, but present today even if some people are oblivious to it. As critical race theorists argue, the social structure that the white men are on top still exists in American society as a result of the continued presence of de facto segregation. This frontal message also implies that the symptoms of caste can seem very small or very coincidental but are the results of the time of de jure segregation. Wilkerson carefully builds the image of caste as an imperishable cage in society with this masterfully compiled series of stories and studies, which serves first and foremost as a reminder that America's past problems have only been carried over.

In conclusion, Caste by Isabel Wilkerson takes a unique way to present the subject of racism and the caste system that has been imposed in American society. Through a new narrative approach, which focuses on many individual stories and parallels to create a broader picture, this work contributes to building a clearer understanding of the vastness and depth of the caste system. It 
is a very illuminative work on the reality of racial relations and the influence of racial politics in American society, demonstrating how the caste system has been molded into society all the way into the present.

\section{REFERENCES}

De La Garza, A. T. (2015). “A Critical Eulogy for Joaquin Luna: Mindful Racial Realism as an Intervention to End Racial Battle Fatigue," in Racial Battle Fatigue: Insights from the Front Lines of Social justice Advocacy. Editor J. Martin (New York, NY: Praeger), 177-190.

De La Garza, A. T., and Ono, K. A. (2016). "Critical Race Theory," in The International Encyclopedia of Communication Theory and Philosophy. Editors K. B. Jensen and R. T. Craig (Hoboken, NJ: John Wiley \& Sons), 319-399.

Orbe, M. P., and Allen, B. J. (2008). "Race Matters" in theJournal of Applied Communication Research. Howard J. Commun. 19, 201-220. doi:10.1080/ 10646170802218115

\section{AUTHOR CONTRIBUTIONS}

The author confirms being the sole contributor of this work and has approved it for publication.

Conflict of Interest: The author declares that the research was conducted in the absence of any commercial or financial relationships that could be construed as a potential conflict of interest.

Publisher's Note: All claims expressed in this article are solely those of the authors and do not necessarily represent those of their affiliated organizations, or those of the publisher, the editors and the reviewers. Any product that may be evaluated in this article, or claim that may be made by its manufacturer, is not guaranteed or endorsed by the publisher

Copyright (C) $2021 \mathrm{Kim}$. This is an open-access article distributed under the terms of the Creative Commons Attribution License (CC BY). The use, distribution or reproduction in other forums is permitted, provided the original author(s) and the copyright owner(s) are credited and that the original publication in this journal is cited, in accordance with accepted academic practice. No use, distribution or reproduction is permitted which does not comply with these terms. 